\title{
Effect of Mushroom, Oat and Their Mixtures as Functional Foods on Antioxidant Activities, Hematological Parameters of Obese Rats and its Sensory Evaluation
}

\author{
Tesby M. R. Lotfy ${ }^{1}$, Hassan A. R. El-Hendy ${ }^{2}$, Samar M. S. Shawir ${ }^{1}$
}

\begin{abstract}
The present investigation aimed to evaluate the effect of mushroom /oat and their mixtures on antioxidant activities, hematological parameters of obese rats and sensory attributes of their food products. Male albino rats $(n=48)$ were divided into two main groups, the first main group ( $n=6$ rats) fed on basal diet as a control negative group (G1). The second main group ( $n=42$ rats) received HFD for 8 weeks to induce obesity in rats. Then high fat diet group was divided into (7) sub-groups $(n=6$ rats for each), the first sub-group fed on HFD as a control positive group (G2). G3 fed on positive diet and mushroom $10 \%$, G4 fed on positive diet and mushroom $20 \%$, G5 fed on positive diet and oat $20 \%$, G6 fed on positive diet and oat $40 \%$, G7 fed on positive diet and mushroom plus oat $(10+20 \%), \mathbf{G 8}$ fed on positive diet and mushroom plus oat $(20+40 \%)$. After 8 weeks periods, blood samples were collected from group treatments to estimate antioxidant activities and hematological parameters. The results of antioxidant activity showed that HFD rats had the lowest level of SOD, CAT and GPX, whereas the activities were 6.73, 3.20 and 3.97 $\mathrm{U} / \mathrm{g}$ tissue, respectively. The mixtures of mushroom plus oat $(40+20 \%)$ increased the level of SOD, CAT and GPX whereas the activity were 10.33, 6.03 and 9.07 U/g tissue, respectively close to the activity of nonobese (control), 9.23, 6.97 and $9.60 \mathrm{U} / \mathrm{g}$ tissue, respectively. Hematological parameters were improved in the group fed on a high-fat diet containing mushroom plus oat $\mathbf{4 0}+$ $20 \%$ ) compared to the control group (positive control). The results of the sensory attributes showed that the food products containing mushroom plus oat (pizza, kofta, bread and soup) were all accepted by the panelists. The study confirms that the use of mushroom and oat products play a role in reducing and controlling the obesity.
\end{abstract}

Key words: Obese rats, mushroom, oat, antioxidant, sensory Attributes.

\section{INTRODUCTION}

Obesity is an important health problem, Egypt considered one of the top adult obesity rates in the world. Obesity is a chronic disease that raises risk factors for metabolic syndrome, which include hypertension and hyperlipidaemia (Hall et al., 2014). Development of obesity is associated with the influence of genetic and environmental factors and activity. Diet plays an important role contributing to pathophysiology of obesity development. Frequent consumption of high energy foods such as fat foods has role in obesity (Davis, 2016).

Functional food can be very beneficial in reducing fat deposition and preventing obesity. Bigliardi and Galati (2013), demonstrated that functional food affect beneficially one or more target functions in the body, beyond adequate nutritional effects to improve state of health or reduce of risk disease.

Mushroom and oat have been grouped as functional foods they have $\beta$-glucan which is one of the most important components has potent biological function in increasing satiety (Rop et al., 2009; Rathore et al., 2017). Mushroom is one unique food abundant in essential macro and micronutrients, highest in dietary fiber, less calorie producing, low fat and carbohydrate content, good sources of protein, vitamins and minerals (Cheung, 2010; Chi et al., 2017). Moreover, fresh mushrooms contain soluble fiber. mainly beta-glucans and chitosans ((Deepalakshmi \& Sankaran, 2014; Ganesan \& Xu, 2018). Mushrooms also have antioxidants and anti-inflammatory components that are useful to heart, kidney and liver. These bioactive compounds act as chemo-preventive agents and protect most serious diseases, including obesity, and neurodegenerative diseases (Muszyńska et al., 2018). Mushrooms have excellent antioxidants for example, non-enzymatic and enzymatic antioxidants such as catalase (CAT), glutathione peroxidase (GPx), and superoxide dismutase. Antioxidant enzymes level critically affected susceptibility of different tissues to oxidative stress and is related with the development of diabetes (Valverde et al., 2015).

Oat and oat products have attracted attention for their considerable health benefits, such as weight-loss (Rasane et al., 2015; Dong et al., 2016). These physiological benefits of oat are generally attributed to $\beta$-glucan. Significant amounts of $\beta$-glucan associated with functional properties including lipid lowering (Wood, 2010; Peng et al., 2013). Oat grains as nutritional value minimize processed oat groat and

DOI: 10.21608/ASEJAIQJSAE.2021.144248

${ }^{1}$ Home Economics Department, Faculty of Specific Education,

Alexandria University, Alexandria, Egypt

${ }^{2}$ Department of Home Economics, Faculty of Agriculture,

Alexandria University, Alexandria, Egypt

Received December 16, 2020, Accepted January 28, 2021 
weight loss was related to the higher level of oat intake. $\beta$-glucan fiber attracts water molecule and increases thickness of digested food this slows absorption rate of nutrients, which in turn increases weight loss ( $\mathrm{Li}$ et al., 2016; Rebello et al., 2016). Oat also contains phenolic compounds such as ferulic acid and aventiramidate (AVA) that may contribute to the functional and nutritional properties of oat and have activities as antioxidant, anti-inflammatory and anti-reproductive ((Boz, 2015; Călinoiu \& Vodnar, 2018). Oat also contain antioxidant compounds such as tocopherols and tocotrienols present in the outer layer oat grain (Gani et al., 2012; Martinez-Villaluenga \& Peñas, 2017).

Hematological parameters such as red (RBC) and white blood cell (WBC) counts and hemoglobin ( $\mathrm{Hb})$ concentration are tightly regulated traits with high clinical relevance. Values outside normal ranges are diagnostic for disorders, immune diseases, and cardiovascular disease (Lin et al., 2007). Hematological parameters are affected by many factors such as age, race, diet, genetic and gender differences. Indicators such as red cell distribution (RDW) width, average platelet size (MPV), and platelet distribution (PDW) width are hematological parameters and considered evidence as good bio markers (Budak et al., 2016). The number of RBCs count often refer to the imbalance between production and loss of RBCs, anemia usually arises from the reduction of erythrocytes production (Sirag, 2009). Regarding the marked decrease in white blood cell count, it may reflect changes in immune function. The decrease in the number of platelets may be due to inhibition of bone marrow activity (Thiagarajan \& Besa, 2016). Kozarski et al. (2015), reported that eating mushroom caused an improvement in most of the recorded blood parameters due to preventing free radicals caused by damage through their antioxidant activity achieved by the effect of their various phytochemical contents. Baba et al. (2016), investigated oat extract on growth performance, hematological and immunological parameters in common carp they reported that biochemical and immunological indices. Hemoglobin ( $\mathrm{Hb})$, mean hemoglobin (MCH) and mean cellular hemoglobin concentration (MCHC) increased with a diet contain oat extract.

Supplementing wheat flour with up to $10 \%$ mushroom flour produced baked products with high nutritional quality for improved health (Ndung'u et al. (2015). They Mishra et al. (2018), Also concluded that addition of mushroom either in fresh or dry form has improved especially the nutritional content of daily food items. Farzana et al. (2019), stated that fortification of wheat flour with mushroom and oat flour has significant effects on the nutritional, physical and sensory attributes. Depending on the nutritional and sensory results, it can be concluded that flour fortified with $5 \%$ mushroom and $15 \%$ oat is acceptable in quality and it is nutritionally superior over locally available flours.

Zaki and Hussien (2018), reported that samples of biscuits were acceptable, contained oat flour had superior sensory characteristics, nutritional value were acceptable and suitable for diabetic and obesity.

The objective of current study is to evaluate the effect of mushroom and/ or oat and their mixtures in enriched diet on activity of antioxidant enzymes and hematological parameters of obese rats, sensory attributes of their food products is also considered.

\section{MATERIALS AND METHODS}

\section{Materials:}

\section{Mushroom and Oat}

The Oyster mushroom "Pleurotus ostreatus" and Oat "Avena sativa" used in this investigation was purchased from local market in Alexandria, Egypt.

\section{Chemicals and Kits}

-All chemicals used were of analytical and purified grade provided from Merck (Darmstadt, Germany), Sigma-Aldrich Sigma Chemical Co. (St. Louis, MO, USA).

-Commercial kits were obtained from Biosystems S.A. (Spain), Diamond (Germany) and Randox (United Kingdom).

\section{Animals}

Forty-eight male albino rats of Westar strain used in the present experiment, weighting 120-150gm were obtained from Institute of Graduate Studies and Research, Alexandria University. Rats were housed in wire cages under the normal laboratory conditions and were fed on basal diet for two weeks as an adaptation period. Food and water provided ad-labitum and checked daily.

\section{Methods:}

\section{Preparation of dried Oyster Mushroom and Oat powder}

Fresh Oyster mushroom, free of blemishes or obvious defects were washed and cut into pieces. Then dried in an electric oven at $40^{\circ} \mathrm{C}$ for completely dry. After drying, samples was grind in Grinder (Moulinex LM2428EG - 400 Watt, Germany) and then kept in Polyethylene bags in the refrigerator until used (da Silva et al., 2009).

The Oat grains were also grind in a Grinder (Moulinex LM2428EG - 400 Watt, Germany) for about 1 minutes until obtaining of fine, powdery flour. Then kept in Polyethylene bags in the refrigerator until used. 


\section{Experimental design}

The experiment was carried out at Graduate Studies and Research, Alexandria University. Rats were housed in wire cages in a room temperature $25^{\circ} \mathrm{C}$ and kept under normal healthy conditions. After two weeks acclimatization period, rats were divided into two main groups. The first group (6 rats) were fed the basal diet, second group (42 rats) were fed on positive diet (basal diet plus animal fat 20\%) for eight weeks after that samples of blood were taken from rats that fed on basal diet and rat fed on HFD and serum was used to confirm that obesity occurs through determine lipid profile ratio of triglycerides and cholesterol on the two groups; control (C-ve), fed on standard diet only and HFD which divided into 7 subgroups (each 6 rats) which then fed for another 8 weeks as follows: Group 2 :( $\mathrm{C}+\mathrm{ve}$ ): fed on positive diet (basal diet plus plant and animal fat 20\%). Group 3: fed on positive diet and low dose of mushroom (10\%). Group4: fed on positive diet and high dose of mushroom (20\%). Group 5: fed on positive diet and low dose of oat (20\%). Group 6: fed on positive diet and high dose of oat (40\%). Group7: fed on positive diet and low doses mixture of mushroom plus oat $(10+20 \%)$. Group 8: fed on positive diet and high doses mixture of mushroom plus oat $(20+40 \%)$.

\section{Blood sampling:}

At the end of experimental period rats were fasted over night before sacrificing. Blood collected and serum separated and used for measuring hematological parameters and activity of antioxidant enzymes.

\section{Determination of antioxidant enzymes in serum}

Activity of Glutathione peroxidase was determined according to the method described by Wendel (1980). Catalase activity was determined according to the method described by Sinha (1972) and Superoxide dismutase activity was determined according to the method described by Rigo et al. (1975).

\section{Determination of hematological parameters Complete Blood Count (CBC)}

Hemoglobin concentration was determined by method of Shawky (2015). Packed cell volume (PCV) and the red cells (RBC), white blood cells (WBC) were counted under the low power of microscope (Jopling et al., 2009).

\section{Sensory attributes of mushroom and oat mixture food products}

Some mushroom and oat food products (pizza, Kofta, bread and soup) were prepared and evaluated for overall acceptability. The sensory parameters members were evaluated according to Watts et al. (1989) by 40 persons from staff and students of Faculty of specific Education, Alexandria University. Parameters were color, taste, odor, and flavor. The mean value of these sensory parameters was evaluated as overall acceptability which was determined as the total mean score of all the sensory parameters. The 9point Hedonic scale with a scale ranging from 1(representing extreme dislike) to 9 (representing extreme like) was used to evaluate the sensory attributes.

Preparing of some food products of mushroom plus oat

Some food products of mushroom and oat mixtures were prepared for evaluating sensory attributes The amount of mushroom and oat mixtures consumed by rats was transferred to the corresponding amount of human intake according to Paget and Barnes (1964) equation.

\section{1-Wheat flour pizza and mushroom plus oat flour Pizza}

The ingredients of wheat flour pizza as a control and mushroom plus oat flour Pizza are presented in table (1).

Table 1. Ingredient and quantity of Pizza

\begin{tabular}{lclc}
\hline \multicolumn{1}{c}{ Pizza of wheat flour } & \multicolumn{2}{c}{ Pizza of mushroom plus oat flour } \\
\hline Ingredients & Quantity & \multicolumn{1}{c}{ Ingredients } & Quantity \\
\hline wheat flour & $500 \mathrm{~g}$ & oat flour & $370 \mathrm{~g}$ \\
Yeast & $10 \mathrm{~g}$ & mushroom pieces & $185 \mathrm{~g}$ \\
Sugar & $2.5 \mathrm{~g}$ & Yeast & $10 \mathrm{~g}$ \\
Salt & $5 \mathrm{~g}$ & Sugar & $2.5 \mathrm{~g}$ \\
Water & $200 \mathrm{ml}$ & Salt & $5 \mathrm{~g}$ \\
Oil & $10 \mathrm{ml}$ & water & $200 \mathrm{ml}$ \\
Onion sliced & $1 \mathrm{onion}$ & Oil & $10 \mathrm{ml}$ \\
tomato sauce & $250 \mathrm{gm}$ & Onion sliced & $1 \mathrm{onion}$ \\
Tomato & 2 tomatoes & tomato sauce & $250 \mathrm{~g}$ \\
Bell pepper & 2 peppers & tomato & 2 tomatoes \\
Olive & 10 olives & Bell pepper & 2 peppers \\
Mozzarella cheese & $250 \mathrm{~g}$ & olive & 10 olives \\
& & Mozzarella cheese & $250 \mathrm{~g}$ \\
\hline
\end{tabular}




\section{Method of preparing common pizza}

Dry ingredient pf pizza (wheat flour, yeast, sugar and salt) was mixed then warm water was added to the mixture slowly until dough was formed then dough was incubated in a warm place for 30 min till fermentation. After that dough was cut into spherical pieces and pieces spread to form circle shape then left for another $20 \mathrm{~min}$ for fermentation. After fermentation circles of dough placed in pizza tray about 12-inch diameter and tomato sauce was added over each circle, then onion, tomato, pepper, olive slices and mozzarella cheese was placed on the sauce After that the pizza tray placed on oven at about $180^{\circ} \mathrm{c}$ and cooked for 15 minutes until used for sensory attributes (Saba, 2012).

\section{The recipe of pizza of mushroom plus oat flour.}

In the case of mushroom plus oat pizza wheat flour was replaced by oat flour and mushroom pieces.

\section{1-Kofta of meat and Kofta of mushroom plus oat}

The ingredients of meat kofta (Daoud Basha) as a control and sauce kofta of mushroom plus oat are presented in table (2).

Method of preparing meat kofta (Daoud Basha)
Meat was blended in electric blender then green coriander salt and black pepper was added to meat and mixed well until obtaining homogenous mixture, then medium sized of meat balls was prepared oil transferred to pan and heated than balls of meat placed on the pan and stirring was done for 5 minutes until meat balls turned to brown color then removed from the pan. Onions transferred to the pan that contain oil and heated with stirring until the color of onion turned bronze then garlic added and stirred for minutes over heat after than blended tomato was added to the pan that contain onion, garlic and stirred again. After that balls of meat was added to the pan containing the previous mixture and mixed gently until became homogeneous and heated for 20 minutes until the kofta cooked (Saba, 2012).

\section{The recipe of sauce Kofta of mushroom plus oat}

In the case of mushroom plus oat kofta, meat was replaced by mushroom pieces and oat flour.

\section{2-Meat soup and mushroom plus oat soup}

The ingredients of meat soup as a control and mushroom plus oat soup are presented in table (3).

Table 2. Ingredients and quantity of sauce kofta

\begin{tabular}{cccccccc}
\hline \multicolumn{3}{c}{ kofta of meat (Daoud Basha) } & \multicolumn{4}{c}{ sauce kofta of mushroom plus oat } \\
\hline $\begin{array}{c}\text { Ingredients } \\
\text { (sauce) }\end{array}$ & Quantity & $\begin{array}{c}\text { Ingredients } \\
\text { (Kofta) }\end{array}$ & Quantity & $\begin{array}{c}\text { Ingredients } \\
\text { (sauce) }\end{array}$ & Quantity & $\begin{array}{c}\text { Ingredients } \\
\text { (Kofta) }\end{array}$ & Quantity \\
\hline Onions & One onion & Minced meat & $500 \mathrm{~g}$ & Onions & One onion & oat flour & $370 \mathrm{~g}$ \\
Garlic & $20 \mathrm{~g}$ & salt & $5 \mathrm{~g}$ & Garlic & $20 \mathrm{~g}$ & Mushroom & $185 \mathrm{~g}$ \\
Tomato & $1 \mathrm{~kg}$ & Black Pepper & $1 \mathrm{~g}$ & Tomato & $1 \mathrm{~kg}$ & salt & $5 \mathrm{~g}$ \\
Water & $100 \mathrm{ml}$ & Vegetable oil & $10 \mathrm{ml}$ & Water & $100 \mathrm{ml}$ & Black Pepper & $1 \mathrm{~g}$ \\
Salt & $5 \mathrm{~g}$ & green coriander & $5 \mathrm{~g}$ & Salt & $5 \mathrm{~g}$ & Vegetable oil & $10 \mathrm{ml}$ \\
Black Pepper & $1 \mathrm{~g}$ & & & Black Pepper & $1 \mathrm{~g}$ & green & $5 \mathrm{~g}$ \\
\hline
\end{tabular}

Table 3. Ingredients and quantity of soup

\begin{tabular}{lclc}
\hline \multicolumn{1}{c}{ meat soup } & \multicolumn{2}{c}{ mushroom plus oat soup } \\
\hline Ingredients & Quantity & \multicolumn{1}{c}{ Ingredients } & Quantity \\
Meat & $500 \mathrm{~g}$ & Oat flour & $370 \mathrm{~g}$ \\
Black Pepper & $5 \mathrm{~g}$ & Oyster mushroom & 185 \\
Cardamom & $1 \mathrm{~g}$ & Salt & $5 \mathrm{~g}$ \\
Mistekah & 3 grains & Black Pepper & $1 \mathrm{~g}$ \\
Onion (chopped) & 2 grains & Onion (chopped) & $2 \mathrm{~kg} / 1$ \\
Vegetable oil & $2 \mathrm{~kg} / 1$ & Low fat cream & $20 \mathrm{ml}$ \\
Water & $10 \mathrm{ml}$ & Vegetable oil & $10 \mathrm{ml}$ \\
\hline
\end{tabular}




\section{Method of preparing meat soup}

Vegetable oil was placed in suitable container and chopped onions was added and cooked on suitable temperature then meat, cardamom, mistekah, salt and pepper powder added and cooked for 3 minutes on high temperature. Then water added and cook for 30 minutes on high temperature until soup ready for sensory attributes (Saba, 2012).

\section{The recipe of mushroom plus oat soup}

In the case of mushroom plus oat soup, meat was replaced by mushroom pieces and oat flour.

\section{3-White bread and mushroom plus oat bread}

The ingredients of white bread as a control and mushroom plus oat bread are presented in table (4).

Table 4. Ingredients and quantity of bread

\begin{tabular}{lclc}
\hline \multicolumn{2}{c}{ White bread } & \multicolumn{2}{c}{ Mushroom plus oat bread } \\
\hline Ingredients & Quantity & Ingredients & Quantity \\
\hline Wheat flour & $400 \mathrm{~g}$ & Oat flour & $370 \mathrm{~g}$ \\
Sugar & $2 \mathrm{~g}$ & Mushroom & $185.1 \mathrm{~g}$ \\
Salt & $2.25 \mathrm{~g}$ & Sugar & $2 \mathrm{~g}$ \\
Yeast & $15 \mathrm{~g}$ & Salt & $2.25 \mathrm{~g}$ \\
Water & $200 \mathrm{ml}$ & Yeast & $15 \mathrm{~g}$ \\
Milk & $25 \mathrm{ml}$ & Water & $250 \mathrm{ml}$ \\
& & Skimmed & $50 \mathrm{ml}$ \\
& & milk & \\
\hline
\end{tabular}

\section{Method of preparing white Bread}

To prepare bread first dough was prepared by mixing the dry ingredients together (flour, salt, dry yeast and sugar). Then milk and warm water were added slowly until dough was formed then dough was incubated in a warm place for $30 \mathrm{~min}$ till fermentation. After that dough was cut into spherical pieces and spread to circle shape loaf then left for another $20 \mathrm{~min}$ for fermentation then loaf was baked on medium heat on Tefal pan until beaked loaf (Saba, 2012).

\section{The recipe of mushroom plus oat bread}

In the case of mushroom plus oat bread, wheat flour was replaced by oat flour and mushroom, then warm water and skimmed milk (added for reducing the odor of mushroom and improving the taste) was added slowly until dough

\section{Statistical analysis}

Data were analyzed using IBM SPSS software package version 20.0. (Armonk, NY: IBM Corp). Quantitative data was described using mean, standard error. Significance of the obtained results was judged at the 5\% level. Student t-test used for normally distributed quantitative variables, to compare between two studied groups and F-test (ANOVA) used for normally distributed quantitative variables, to compare between more than two groups, and Post Hoc test (LSD) for pairwise comparisons (Kirkpatrick \& Feeney, 2013).

\section{RESULTS AND DISCUSSION}

The effect of mushroom and oat treatments at different levels on activities of antioxidant enzymes in the serum of obese rats

The levels of the activities of antioxidant enzymes superoxide dismutase, catalase (CAT) and glutathione peroxidase (GPx) were measured in serum of rats feed on basal diet (control -), rats fed on high fat diet (control +) and rat fed with HFD and supplemented with different levels of mushroom and oat beside their mixtures. The data in Tables (5) showed that HFD rats had the lowest level of SOD activity compared with the other treatment and control. Whereas the concentration of SOD was $6.73 \mathrm{U} / \mathrm{g}$ in HFD compared with 9.23, 9.37 and $10.33 \mathrm{U} / \mathrm{g}$ in control (-), mushroom plus oat $(20+10 \%)$ and mushroom plus oat $(20+40 \%)$, respectively. The results showed that the mixtures of mushroom plus oat at the two levels increase the level of SOD activity closed to the non-obese compared with the other treatments which showed moderate increase of SOD activity. Also, the HFD rats showed the lowest level of CAT activity compared with the other treatment and control. Whereas the concentration of CAT was $3.20 \mathrm{U} / \mathrm{g}$ in HFD compared with 6.97, 5.50 and $6.03 \mathrm{U} / \mathrm{g}$ in control (-), mushroom plus oat $(20+10 \%)$ and mushroom plus oat $(20+40 \%)$, respectively. Also, the results showed that the mixtures of mushroom plus oat at the two levels increase the level of CAT near to the nonobese compared with the other treatments which showed moderate increase of CAT activity. Moreover, the HFD rats showed the lowest level of GPX activity compared with the other treatment and control. Whereas the concentration of GPX was $3.97 \mathrm{U} / \mathrm{g}$ in HFD compared with $9.60,8.30$ and $9.07 \mathrm{U} / \mathrm{g}$ in control (-), mushroom plus oat $(20+10 \%)$ and mushroom plus oat $(20+40 \%)$, respectively. The results showed that the mixtures of mushroom plus oat at the two levels increased the level of GPX activity close to the non-obese compared with the other treatments which showed moderate increased of GPX activity. The current study, showed that mushrooms possibly have antioxidant capacities that increased the antioxidant of body defense systems and thereby might protect against obesity. So, consumption of mushrooms might be effective for treatment against obesity, and thus could be a good candidate for use in future for dietary applications. The beneficial amounts of the bioactive compounds that present in mushroom such as (polysaccharides, fibers, polyphenols and flavonoids), which considered antioxidant components make mushroom potential for dietary regime against obesity. Also, oat has an adequate dietary antioxidant for good protection and maintenance of tissue against redox balance. 
So, intake of antioxidants as well as phytochemicals that present in oat diet is linked with oxidant-antioxidant imbalance in obesity.

Shawky (2015), mentioned that HFD exhibited a significant decrease in SOD activity. These findings are in accordance with those of Galaly et al. (2014), who stated that male rats fed with a high fat diet had significantly lower levels of SOD compared with the control diet male rats. Obesity may induce oxidative stress and increase oxidative stress. Moreover Kaushal et al., 2018,reorted that treatment with the extract of $\mathrm{P}$. ostreatus mushroom appeared to exert a beneficial effect since the activities of CAT and SOD were significantly higher in liver compared with control. No such significant difference between mean Gpx activities in the different groups of rats was observed. The mushroom extract of Pleurotus florida increase the levels antioxidant enzymes. In contrast Sirag (2009), investigated the effect of mushroom administration on the activities of renal SOD. The data revealed that, mushroom administration daily for 3 weeks did not induce significant changes in the tested parameter as compared with those of control.Valverde et al. (2015), indicated that mushrooms was an excellent antioxidants and anti-inflammatory. Moreover, mushroom polysaccharides contain antioxidant which might be effective for preventing some diseases
Zhang et al. (2020), indicated that oat consumption increased activities of superoxide dismutase, glutathione peroxidase and catalase; moreover, total enzyme activities of SOD, GPx and CAT in the liver of the HFD group were obviously decreased compared with control group. Many study indicated that HFD-induced obesity decreased antioxidant enzyme activity (Lugogo et al., 2011; Jin et al., 2013). Friedman (2016), reported the potential of mushroom polysaccharides to treat high-fat diet-induced obesity and diminished oxidative stress. Boz (2015), reported that oat contains more phenolic compounds, which have anti-oxidant activities, anti-inflammatory and anti-reproductive. The bioavailability of polyphenols in oat that associated with improving antioxidant status. Grundy et al. (2018), confirmed that oat antioxidants have the potential of reducing inflammation and oxidative stress. The current results showed that HFD rats had the lowest level of SOD, CAT and GPX. The mixtures of mushroom plus oat at the two levels increased the levels of SOD, CAT and GPX activities close to the non-obese compared with the other treatments which showed moderate increase of SOD.

Table 5. Activities of antioxidant enzymes of rats fed on high fat diet (HFD) and treated with mushroom and oat in the serum of obese rats

\begin{tabular}{|c|c|c|c|c|}
\hline \multirow{3}{*}{ Groups } & \multirow{3}{*}{ Treatments } & \multicolumn{3}{|c|}{ Antioxidant enzymes } \\
\hline & & SOD & CAT & GPX \\
\hline & & \multicolumn{3}{|c|}{ (U/g tissue) } \\
\hline G1 & Control (-) & $9.23^{\mathrm{a}} \pm 0.78$ & $6.97^{\mathrm{a}} \pm 0.12$ & $9.60^{\mathrm{a}} \pm 0.21$ \\
\hline $\mathrm{G} 2$ & $\operatorname{HFD}(+)$ & $6.73^{\mathrm{b}} \pm 0.23$ & $3.20^{\mathrm{e}} \pm 0.51$ & $3.97^{\mathrm{f}} \pm 0.24$ \\
\hline G3 & HFD supplemented with Mushroom 10\% & $8.97^{\mathrm{a}} \pm 0.67$ & $4.53^{\mathrm{cd}} \pm 0.28$ & $6.03^{\mathrm{e}} \pm 0.29$ \\
\hline G4 & HFD supplemented with Mushroom 20\% & $9.43^{\mathrm{a}} \pm 0.39$ & $5.40^{\mathrm{bc}} \pm 0.36$ & $7.17^{\text {cde }} \pm 0.58$ \\
\hline G5 & HFD supplemented with Oat $20 \%$ & $10.03^{\mathrm{a}} \pm 0.42$ & $5.57^{\mathrm{b}} \pm 0.33$ & $6.97^{\mathrm{de}} \pm 0.44$ \\
\hline G6 & HFD supplemented with Oat $40 \%$ & $9.43^{\mathrm{a}} \pm 0.49$ & $4.43^{\mathrm{d}} \pm 0.35$ & $7.37^{\mathrm{cd}} \pm 0.64$ \\
\hline G7 & $\begin{array}{l}\text { HFD supplemented with Mushroom and Oat }(10 \% \\
+20 \%)\end{array}$ & $9.37^{\mathrm{a}} \pm 0.59$ & $5.50^{\mathrm{b}} \pm 0.06$ & $8.30^{\mathrm{bc}} \pm .12$ \\
\hline \multirow[t]{4}{*}{ G8 } & $\begin{array}{l}\text { HFD supplemented with Mushroom and Oat }(20 \%+ \\
40 \%)\end{array}$ & $10.33^{\mathrm{a}} \pm 0.62$ & $6.03^{b} \pm 0.12$ & $9.07^{\mathrm{ab}} \pm 0.09$ \\
\hline & $\mathrm{F}$ & $3.911^{*}$ & $14.031^{*}$ & $22.250^{*}$ \\
\hline & $\mathrm{P}$ & $0.011^{*}$ & $<0.001^{*}$ & $<0.001^{*}$ \\
\hline & LSD $5 \%$ & 1.6462 & 0.9132 & 1.1334 \\
\hline
\end{tabular}

Data was expressed as Mean \pm SE.

Means in a column with same letters are not significant (and Means with Different letters are significant)

*: Statistically significant at $\mathrm{p} \leq 0.05$ 
2- The effect of mushroom and oat treatments at different levels on hematological parameters.

\section{Red blood cells (RBCs)}

Hematological parameters of red blood cell and platelet count in the serum of rats feed on basal diet (control -), rats fed on high fat diet (control +) and rat fed with HFD and supplemented with different levels of mushroom and oat beside their mixtures is presented in Table (6). The data showed that the concentration of Hemoglobin in HFD rats was low compared with the other treatments and control (-). Whereas the concentration of Hemoglobin was $11.47 \mathrm{~g} / \mathrm{dl}$ in HFD compared with $13.87,15.37$ and $15.60 \mathrm{~g} / \mathrm{dl}$ in control (), mushroom plus oat $(10+20 \%)$ and mushroom plus oat $(20+40 \%)$, respectively. The mixtures of mushroom plus oat increased the level of Hemoglobin higher than the level in the non-obese rats. In the meantime, the Red Cell Count in the HFD rats showed the lowest number compared with the other treatments and control (-). The mixtures of mushroom plus oat at the two levels increased the Red Cell Count, the percentage of Haematocrit, the level of M.C.V and the level of M.C.H compared with HFD and while the level of M.C.H.C was reduced in mixture of mushroom plus oat treatment compared with HFD and non-obese rats. While, the results showed that the mixtures of mushroom plus oat at the two levels reduced the percentage of R.D.W-CV compared with HFD and non-obese rats. The platelet count in the HFD rats showed the lowest concentration compared with the other treatments and control (-). Whereas, the concentration of platelet count was (366.6 $\left.\mathrm{x} 10^{3} / \mathrm{ul}\right)$ in HFD compared with $600.3 \times 10^{3}, 680.3 \times 10^{3}$ and $844.0 \times 10^{3} / \mathrm{ul}$, in control (-), mushroom plus oat $(10+20 \%)$ and mushroom plus oat $(20+40 \%)$, respectively. The results showed that the mixtures of mushroom plus oat at the two levels increase the level of platelet count close to that estimated in the nonobese. In general, most of the hematological parameters; Hemoglobin concentration, Red Cell Count, Haematocrit, mean corpuscular volume (M.C.V), Mean corpuscular
Hemoglobin (M.C.H), mean corpuscular hemoglobin concentration (M.C.H.C), and Platelet count in the serum were reduced in HFD rats while increased in the nonobese, and mushroom and /or oat treatments, except Red blood cell distribution width (R.D.W-CV) parameter that increased in HFD treatments compared with the other treatments.

In general, most of the tested hematological parameters the blood were reduced in HFD rats while increased the non-obese, and mushroom and /or oat treatments, except Red blood cell distribution width (RDW-CV) parameter that increased in HFD treatments compared with the other treatments. The current study showed significant effect of mushroom and oat on hematological parameters therefore these two functional foods or their products can be used for medicinal treatment for anemia and blood clotting disorders.

Our results in agreement with that reported by Kozarski et al. (2015) in which mushroom as functional food improved most investigated hematological parameters. Also, Baba et al. (2016), reported that, Haemoglobin, mean hemoglobin and mean cellular hemoglobin concentration increased dependent on diet that contain oat product. Sirag (2009), showed that hematological data of RBCs, platelets counts, Hb, Hct, MCV and MCH values a varied in rats treated with glycerol and control group. The administration of mushroom pre-glycerol injection resulted in a pronounced improvement in most of them. The reduction in platelets counts with subsequent decline in the values of $\mathrm{Hb}, \mathrm{Hct}, \mathrm{MCV}$ and $\mathrm{MCH}$. In contrast Shawky (2015), reported that hematological parameters in HFD rats exhibited no significant changes in $\mathrm{Hb}$, $\mathrm{PCV}$, and RBCs, compared with control and that may be attributed to the change in hematological parameters as a result of high fat diet may need long term exposure not short term. 
Table 6. Effect of mushroom and oat treatments at different levels on hematological (RBCs) parameters in the blood of obese rats

\begin{tabular}{|c|c|c|c|c|c|c|c|c|c|}
\hline Groups & Treatments & $\begin{array}{l}\text { Hemoglobin } \\
\text { Conc. }(\mathrm{g} / \mathrm{dl})\end{array}$ & $\begin{array}{l}\text { Red Cell Count } \\
\quad\left(\mathrm{x} 10^{6}\right)\end{array}$ & $\begin{array}{l}\text { Haematocrit } \\
(\mathrm{PCV})(\%)\end{array}$ & $\begin{array}{l}\text { M.C.V } \\
\text { (fL) }\end{array}$ & $\begin{array}{c}\text { M.C.H } \\
\text { (Lopes- } \\
\text { Virella et al.) }\end{array}$ & $\begin{array}{l}\text { M.C.H.C } \\
(\mathrm{g} / \mathrm{dl})\end{array}$ & $\begin{array}{l}\text { R.D.W-CV } \\
\qquad \%)\end{array}$ & $\begin{array}{l}\text { Platelet count } \\
\quad\left(\times 10^{3} / \mathrm{ul}\right)\end{array}$ \\
\hline G1 & Control (-) & $13.87^{\mathrm{b}} \pm 0.09$ & $5.20^{\mathrm{bcd}} \pm 0.56$ & $41.47^{\mathrm{bc}} \pm 0.49$ & $75.10^{\mathrm{d}} \pm 0.60$ & $24.13^{\mathrm{c}} \pm 0.52$ & $33.37^{\mathrm{ab}} \pm 0.20$ & $16.57^{\mathrm{ab}} \pm 0.58$ & $600.3^{\mathrm{d}} \pm 0.88$ \\
\hline $\mathrm{G} 2$ & $\mathrm{HFD}(+)$ & $11.47^{\mathrm{e}} \pm 0.18$ & $4.03^{\mathrm{d}} \pm 0.27$ & $35.60^{\mathrm{e}} \pm 0.53$ & $50.07^{\mathrm{g}} \pm 0.54$ & $16.67^{\mathrm{f}} \pm 0.29$ & $31.17^{c} \pm 0.73$ & $16.90^{\mathrm{a}} \pm 0.76$ & $366.6^{\mathrm{h}} \pm 0.32$ \\
\hline G3 & HFD supplemented with Mushroom $10 \%$ & $12.73^{\mathrm{cd}} \pm 0.19$ & $5.0^{\mathrm{cd}} \pm 0.85$ & $40.47^{c} \pm 0.49$ & $58.13^{\mathrm{f}} \pm 0.91$ & $21.23^{\mathrm{d}} \pm 0.63$ & $32.17^{\mathrm{bc}} \pm 0.50$ & $15.0^{\mathrm{b}} \pm 0.95$ & $371.0^{\mathrm{g}} \pm 0.58$ \\
\hline G4 & HFD supplemented with Mushroom 20\% & $13.83^{\mathrm{b}} \pm 0.37$ & $5.30^{\mathrm{bcd}} \pm 0.40$ & $45.90^{\mathrm{a}} \pm 0.53$ & $56.73^{\mathrm{f}} \pm 0.43$ & $19.10^{\mathrm{e}} \pm 0.29$ & $33.0^{\mathrm{ab}} \pm 0.06$ & $13.17^{\mathrm{c}} \pm 0.57$ & $475.0^{\mathrm{f}} \pm 0.58$ \\
\hline G5 & HFD supplemented with Oat $20 \%$ & $13.80^{\mathrm{bc}} \pm 0.55$ & $5.76^{\mathrm{bc}} \pm 0.24$ & $41.50^{\mathrm{bc}} \pm 0.15$ & $66.40^{\mathrm{e}} \pm 0.44$ & $22.20^{\mathrm{d}} \pm 0.44$ & $33.27^{\mathrm{ab}} \pm 0.24$ & $15.03^{\mathrm{b}} \pm 0.32$ & $580.0^{\mathrm{e}} \pm 0.58$ \\
\hline G6 & HFD supplemented with Oat $40 \%$ & $12.20^{\mathrm{de}} \pm 0.50$ & $6.78^{\mathrm{ab}} \pm 0.94$ & $37.60^{\mathrm{d}} \pm 0.46$ & $78.83^{c} \pm 0.96$ & $25.83^{\mathrm{b}} \pm 0.59$ & $32.77^{\mathrm{ab}} \pm 0.27$ & $13.27^{\mathrm{c}} \pm 0.42$ & $637.7^{\mathrm{c}} \pm 0.88$ \\
\hline G7 & $\begin{array}{l}\text { HFD supplemented with Mushroom and Oat } \\
(10 \%+20 \%)\end{array}$ & $15.37^{\mathrm{a}} \pm 0.30$ & $8.15^{\mathrm{a}} \pm 0.54$ & $42.47^{\mathrm{b}} \pm 0.44$ & $82.77^{\mathrm{b}} \pm 0.96$ & $26.93^{\mathrm{b}} \pm 0.78$ & $32.53^{\mathrm{b}} \pm 0.09$ & $13.07^{\mathfrak{c}} \pm 0.42$ & $680.3^{\mathrm{b}} \pm 0.15$ \\
\hline G8 & $\begin{array}{l}\text { HFD supplemented with Mushroom and Oat } \\
(20 \%+40 \%)\end{array}$ & $15.60^{\mathrm{a}} \pm 0.44$ & $8.30^{\mathrm{a}} \pm 0.19$ & $47.10^{\mathrm{a}} \pm 0.89$ & $89.47^{\mathrm{a}} \pm 0.28$ & $29.27^{\mathrm{a}} \pm 0.52$ & $33.80^{\mathrm{a}} \pm 0.60$ & $12.83^{\mathrm{c}} \pm 0.15$ & $844.0^{\mathrm{a}} \pm 0.58$ \\
\hline & F & $16.025^{*}$ & $7.493^{*}$ & $51.536^{*}$ & $416.260^{*}$ & $62.271^{*}$ & $4.054^{*}$ & $8.145^{*}$ & $69054.31^{*}$ \\
\hline & $\mathrm{P}$ & $<0.001^{*}$ & $<0.001^{*}$ & $<0.001^{*}$ & $<0.001^{*}$ & $<0.001^{*}$ & $0.010^{*}$ & $<0.001^{*}$ & $<0.001^{*}$ \\
\hline & LSD 5\% & 1.079 & 1.685 & 1.600 & 2.058 & 1.593 & 1.218 & 1.715 & 1.844 \\
\hline
\end{tabular}

Means in a column with same letters are not significant (and Means with Different letters are significant)

*: Statistically significant at $\mathrm{p} \leq 0.05$ 


\section{White blood cells (WBCs) and differential}

The effect of mushroom and oat treatments at different levels on hematological parameters of White blood cells (WBCs) and differential, Eosinophil's, Neutrophils, Basophils, Lymphocytes, and Monocytes in the serum of rats feed on basal diet (control -), rats fed on high fat diet (control +) and obese rat fed with HFD and supplemented with different levels of mushroom and oat beside their mixtures are presented in Table (7) . The data showed that the number of WBCs in HFD rats was low compared with the other treatments and control (-). Whereas the number of WBCs was 2.87 $\mathrm{x} 10^{3} / \mathrm{ul}$ in HFD treatment compared with $8.03 \times 10^{3}$, $7.90 \times 10^{3}$ and $8.60 \times 10^{3} /$ ul in control (-), mushroom plus oat $(10+20 \%)$ and mushroom plus oat $(20+40 \%)$, respectively. The results showed significant differences between HFD treatment and the other treatments supplemented with different levels of mushroom and oat. The mixtures of mushroom plus oat increased the level of WBCs, Eosinophil's count, Neutrophils and Monocytes close to that in the non-obese rats. While, the percentage of Lymphocytes in the HFD rats treatment were the highest compared with that of other treatments and control. The results showed that the mixtures of mushroom plus oat at the two levels reduced the percentage of Lymphocytes to level closed to that noted in the non-obese rats compared with the other treatments which showed moderate Lymphocytes reduction percentage. In general, most of the hematological parameters of White blood cells (WBCs), and its components, Eosinophil's, Neutrophils and Monocytes in the serum were reduced in HFD rats while increased the non-obese, and mushroom and /or Oat treatments, except percentage of Lymphocytes parameter that increased in HFD treatments compared with the other treatments.Basophils are type of white blood cell they responsible for inflammatory reactions during immune response and chronic diseases. A high basophil levels may also be a signal of low thyroid function. A healthy range is 0 to 3 basophils in each $u l$ of blood (Amundsen et al., 2012). The current results showed no significant differences between all treatments which revealed that the level of basophils in the normal range, in other word all tested rats had no inflammations and no chronic diseases whereas all treatments showed no effect on the level of basophils.

In general, most of the hematological parameters; White blood cells (WBCs), and differential, Eosinophil's, Neutrophils and Monocytes in the blood were reduced in HFD rats while increased the nonobese, and mushroom and /or Oat treatments, except percentage of Lymphocytes parameter that increased in HFD treatments compared with the other treatments.
Therefore, oyster mushroom and oat could be recommended as a good immuno-stimulant to improve immunity and disease resistant because they contains beta glucans that act as immuno-modulator agents, which regulate and creating more efficient immune system.

Our results in line with that reported by Sirag (2009) in which the hematological data showed variation in WBCs values in control group and different treated groups. The administration of mushroom pre-glycerol injection resulted in a pronounced improvement in WBCs. Also Sirimanapong et al. (2015) and Uluköy et al. (2016), reported a significant increase in total WBCs found from the first week up to the sixth week in blood from fish receiving $2 \%$ oyster mushroom supplement to their diet, compared with the control. Monocyte and neutrophil counts were higher in experimental groups than control groups at all sampled weeks. In contrast, lymphocyte count did not display much variation between the control and experimental groups Similarly, the results of Yeganeh et al. (2015) showed that monocyte and neutrophil counts were higher with increasing dietary oyster mushroom extract. In contrast Shawky (2015), reported that HFD rats exhibited no significant changes in WBCs comparing with control one. He also concluded no significant difference in the blood picture of high fat fed rats in compare with control group, this may be attributed to the change in hematological parameters as a result of high fat diet may need long term exposure not short term.

Volman et al. (2008), reported that beta glucans stimulate the activity of macrophages (immune cells) and prevent invading pathogens and other attack of immune cells. Macrophages also release chemicals such as cytokines that help the immune cells to communicate with other cells. In addition, beta glucans stimulate white blood cells killer (lymphocytes) that bind to viruses or tumors and secrete chemicals to destroy it.

Majtan and Jesenak (2018), stated that oat contains Beta-glucans that create more sensitive body to antibiotics and accelerates healing of wounds. Betaglucans also enhance macrophages activity, neutrophils and lethal cells to fight different infections caused by fungi, bacteria and viruses.

Rasane et al. (2015), stated that immune system considered the first line of defense against microbial infections and consumption of oat in the breakfast meal every morning can effectively rapid lymphocytes response mode against infections. Oat are also contain a high level of the amino acid, arginine that plays an important role in immune function maintenance. 
Table 7.Effect of mushroom and oat treatments at different levels on hematological parameters (WBCs) and differential in the blood of obese rats

\begin{tabular}{|c|c|c|c|c|c|c|c|}
\hline \multirow{2}{*}{ Groups } & \multirow{2}{*}{ Treatments groups } & \multicolumn{6}{|l|}{ Parameter } \\
\hline & & $\begin{array}{c}\text { WBCs } \\
\left(\mathrm{x10}^{3} / \mathrm{ul}\right)\end{array}$ & Eosinophil's & Neutrophils & Lymphocytes & Monocytes & $\begin{array}{c}\text { Basophils } \\
\text { (x103/ul) }\end{array}$ \\
\hline G1 & Control (-) & $8.03^{\mathrm{ab}} \pm 0.20$ & $1.77^{\mathrm{a}} \pm 0.34$ & $18.0^{\mathrm{d}} \pm 0.58$ & $74.33^{b} \pm 0.33$ & $4.0^{\mathrm{d}} \pm 0.58$ & $0.0^{\mathrm{a}} \pm 0.0$ \\
\hline $\mathrm{G} 2$ & $\operatorname{HFD}(+)$ & $2.87^{\mathrm{c}} \pm 0.83$ & $1.67^{\mathrm{a}} \pm 0.33$ & $12.34^{\mathrm{e}} \pm 4.16$ & $83.07^{\mathrm{a}} \pm 0.33$ & $3.67^{\mathrm{d}} \pm 0.33$ & $0.0^{\mathrm{a}} \pm 0.0$ \\
\hline G3 & HFD supplemented with Mushroom 10\% & $6.53^{\mathrm{b}} \pm 0.95$ & $2.0^{\mathrm{a}} \pm 0.58$ & $19.67^{\mathrm{cd}} \pm 0.88$ & $71.67^{c} \pm 0.88$ & $4.33^{\mathrm{cd}} \pm 0.67$ & $0.0^{\mathrm{a}} \pm 0.0$ \\
\hline G4 & HFD supplemented with Mushroom 20\% & $7.83^{\mathrm{ab}} \pm 0.72$ & $2.33^{\mathrm{a}} \pm 0.67$ & $20.07^{\mathrm{bcd}} \pm 0.67$ & $71.0^{c} \pm 0.58$ & $4.67^{\mathrm{bcd}} \pm 0.65$ & $0.0^{\mathrm{a}} \pm 0.0$ \\
\hline G5 & HFD supplemented with Oat $20 \%$ & $6.87^{\mathrm{ab}} \pm 0.27$ & $3.0^{\mathrm{a}} \pm 0.58$ & $21.0^{\mathrm{bcd}} \pm 0.58$ & $70.30^{c} \pm 0.65$ & $6.43^{\mathrm{abc}} \pm 0.82$ & $0.0^{\mathrm{a}} \pm 0.0$ \\
\hline G6 & HFD supplemented with Oat $40 \%$ & $7.33^{\mathrm{ab}} \pm 0.55$ & $3.33^{\mathrm{a}} \pm 0.88$ & $23.0^{\mathrm{bc}} \pm 0.58$ & $68.0^{\mathrm{d}} \pm 0.58$ & $6.33^{\mathrm{bc}} \pm 0.88$ & $0.0^{\mathrm{a}} \pm 0.0$ \\
\hline G7 & HFD supplemented with Mushroom and Oat $(10 \%+20 \%)$ & $7.90^{\mathrm{ab}} \pm 0.84$ & $3.98^{\mathrm{a}} \pm 0.56$ & $24.67^{\mathrm{b}} \pm 0.88$ & $64.67^{\mathrm{e}} \pm 0.33$ & $6.67^{\mathrm{ab}} \pm 0.88$ & $0.0^{\mathrm{a}} \pm 0.0$ \\
\hline \multirow[t]{4}{*}{ G8 } & HFD supplemented with Mushroom and Oat $(20 \%+40 \%)$ & $8.60^{\mathrm{a}} \pm 0.46$ & $4.0^{\mathrm{a}} \pm 0.58$ & $31.33^{\mathrm{a}} \pm 0.88$ & $56.33^{\mathrm{f}} \pm 0.88$ & $8.60^{\mathrm{a}} \pm 0.83$ & $0.0^{\mathrm{a}} \pm 0.0$ \\
\hline & F & $7.482^{*}$ & 2.616 & $11.382^{*}$ & $158.887^{*}$ & $5.442^{*}$ & n.s \\
\hline & $\mathrm{P}$ & $<0.001^{*}$ & 0.053 & $<0.001^{*}$ & $<0.001^{*}$ & $0.002^{*}$ & n.s \\
\hline & LSD 5\% & 1.965 & 1.764 & 4.871 & 1.826 & 2.180 & n.s \\
\hline
\end{tabular}

Data was expressed as Mean \pm SE.

Means in a column with same letters are not significant (and Means with Different letters are significant)

*: Statistically significant at $\mathrm{p} \leq 0.05$ 


\section{Sensory properties of mushroom plus oat food products}

Four food products of mushroom plus oat mixture (pizza, Kofta, bread and soup) were prepared and evaluated for overall acceptability compared with control (pizza of wheat flour, Kofta of meat, wheat flour bread and soup of meat). The data in Table (8), and photo (1) showed that evaluation of the sensory parameter of mushroom plus oat Kofta and kofta of meat revealed a significant differences between color, taste, odor, texture and overall acceptability between kofta of meat and mushroom plus oat, whereas kofta meat little more preferable for panelists that have no obesity while mushroom plus oat kofta might be more acceptable for overweight and obesity people. The data in Table (9) and photo (2) showed that evaluation of the sensory parameter of mushroom plus oat pizza and wheat flour pizza revealed no significant differences between all sensory parameters that point to both pizza are acceptable by panelists. The data in Table (10) and photo (3) showed that evaluation of the sensory parameter of mushroom plus oat bread and wheat flour bread revealed significant differences between all sensory parameters that point to wheat flour bread more preferable than mushroom and oat mixture bread which has darken color but we believe that it is good for reducing obesity. Table (11) and photo (4) showed that evaluation of the sensory parameter of mushroom plus oat soup and soup of meat revealed significant differences between all sensory parameters that point to meat soup is preferable for general people than mushroom plus oat soup. In general Table (12) showed overall acceptability of sensory parameters of prepared pizza, Kofta, bread and soup of mushroom and oat mixture which revealed significant differences between the four prepared food products. The results showed that kofta was more acceptable then pizza and bread while soup was the least. In general, the overall acceptability revealed that the four food products which prepared from mushroom plus oat at the high level $(20+40 \%)$ were acceptable for the panelists mostly kofta.
Moreover all the prepared food products of mushroom plus oat considered useful for overweight and people that safer from obesity. Further, all prepared food products might implement in the programs for obesity people to reduce the overweight and to improve the health status and prevent chronic diseases.

Larmkie et al. (2018), subjected consumer-liking tests for two mushroom-based food products, one with cereal blends and the other with $30 \%$ orange flesh yellow potato flour the test established that mushrooms can be incorporated into children's diet. They reported that mushroom-based foods were highly acceptable to children 2 to 5-year-old. Mishra et al. (2018), improved the nutritional value of daily food items through corporation of oyster mushroom in fresh as well as in dry form. They concluded that addition of mushroom either in fresh or dry form has improved especially the nutritional content of daily food items. Farzana et al. (2019), indicated that good quality flour can be prepared by substituting wheat flour with $5 \%$ mushroom flour and addition of oat flours. From the study they stated that fortification of wheat flour with mushroom and oat flour has significant effects on the nutritional, physical and sensory attributes. They concluded that flour fortified with 5\% mushroom and $15 \%$ oat is acceptable in quality and it is nutritionally superior over locally available flours. Moreover, Ndung'u et al. (2015) indicated that supplementing mushrooms with wheat bread increased protein, minerals, B-vitamins, amino acids contents of wheat-mushroom bread compared to wheat bread. Supplementing wheat flour with up to $10 \%$ mushroom flour produced baked products with high nutritional quality for improved health. Zaki and Hussien (2018), showed that sensory attributes of biscuits were acceptable, but sample which contained oat flour had superior sensory characteristics, nutritional value and was suitable for Diabetic and Obesity. In contrast, Bornare and Khan (2015) indicated that increasing level of rolled oat lowered the overall acceptability of cookies.

Table 8. Sensory evaluation of sauce kofta

\begin{tabular}{cccccc}
\hline Kofta & Color & Taste & Odor & Texture & $\begin{array}{c}\text { Overall } \\
\text { acceptability }\end{array}$ \\
\hline Kofta (meat) control & $8.80 \pm 0.07$ & $8.90 \pm 0.05$ & $8.80 \pm 0.05$ & $8.82 \pm 0.06$ & $8.80 \pm 0.07$ \\
Kofta /Oat+ mushroom & $8.53 \pm 0.12$ & $8.62 \pm 0.09$ & $8.59 \pm 0.10$ & $8.59 \pm 0.10$ & $7.72 \pm 0.09$ \\
\hline $\mathrm{T}$ & $2.202^{*}$ & $3.080^{*}$ & $2.851^{*}$ & $2.091^{*}$ & $1.734^{*}$ \\
$\mathrm{P}$ & $0.031^{*}$ & $0.003^{*}$ & $0.006^{*}$ & $0.040^{*}$ & 0.087 \\
\hline
\end{tabular}

t: Student t-test

*: Statistically significant at $\mathrm{p} \leq 0.05$ 


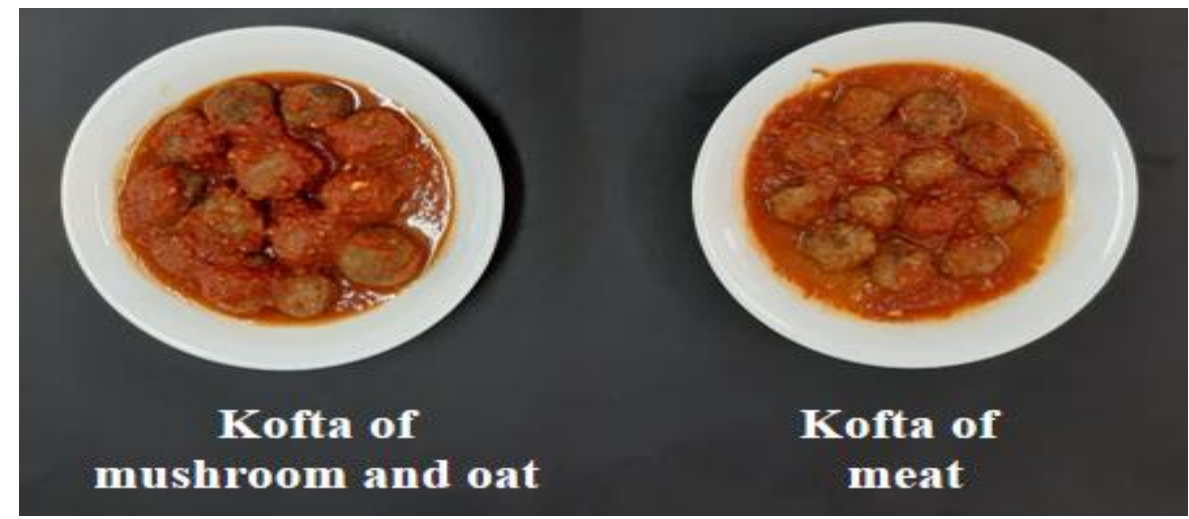

Photo 1. Prepared food product of Kofta

Table 9. Sensory evaluation of Pizza

\begin{tabular}{cccccc}
\hline Pizza & Color & Taste & Odor & Texture & $\begin{array}{c}\text { Overall } \\
\text { acceptability }\end{array}$ \\
\hline Pizza (control) & $8.30 \pm 0.17$ & $8.32 \pm 0.16$ & $8.35 \pm 0.17$ & $8.35 \pm 0.17$ & $8.32 \pm 0.18$ \\
Pizza (Oat+ mushroom) & $8.12 \pm 0.12$ & $8.13 \pm 0.15$ & $8.28 \pm 0.13$ & $8.30 \pm 0.13$ & $8.17 \pm 0.14$ \\
\hline T & 1.074 & 1.003 & 0.348 & 0.238 & 0.813 \\
P & 0.287 & 0.319 & 0.729 & 0.813 & 0.419 \\
\hline
\end{tabular}

t: Student t-test

*: Statistically significant at $\mathrm{p} \leq 0.05$

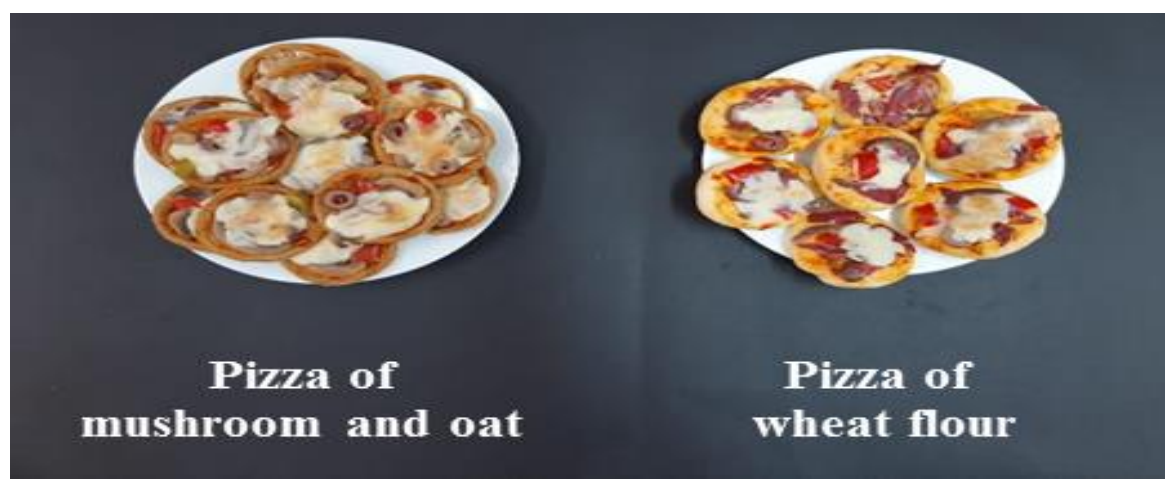

Photo 2. Prepared food product of Pizza

Table 10. Sensory evaluation of Bread

\begin{tabular}{cccccc}
\hline Bread & Color & Taste & Odor & Texture & $\begin{array}{c}\text { Overall } \\
\text { acceptability }\end{array}$ \\
\hline Bread (control) & $8.62 \pm 0.81$ & $8.68 \pm 0.98$ & $8.80 \pm 0.62$ & $8.80 \pm 0.80$ & $8.71 \pm 0.86$ \\
Bread (Oat+ mushroom ) & $7.73 \pm 1.36$ & $8.02 \pm 1.36$ & $8.03 \pm 1.37$ & $8.04 \pm 1.36$ & $7.99 \pm 0.56$ \\
\hline T & 2.498 & $2.648^{*}$ & $3.584^{*}$ & $3.311^{*}$ & $4.926^{*}$ \\
P & $0.015^{*}$ & $0.010^{*}$ & $0.001^{*}$ & $0.002^{*}$ & $<0.001^{*}$ \\
\hline
\end{tabular}

t: Student t-test

*: Statistically significant at $\mathrm{p} \leq 0.05$ 


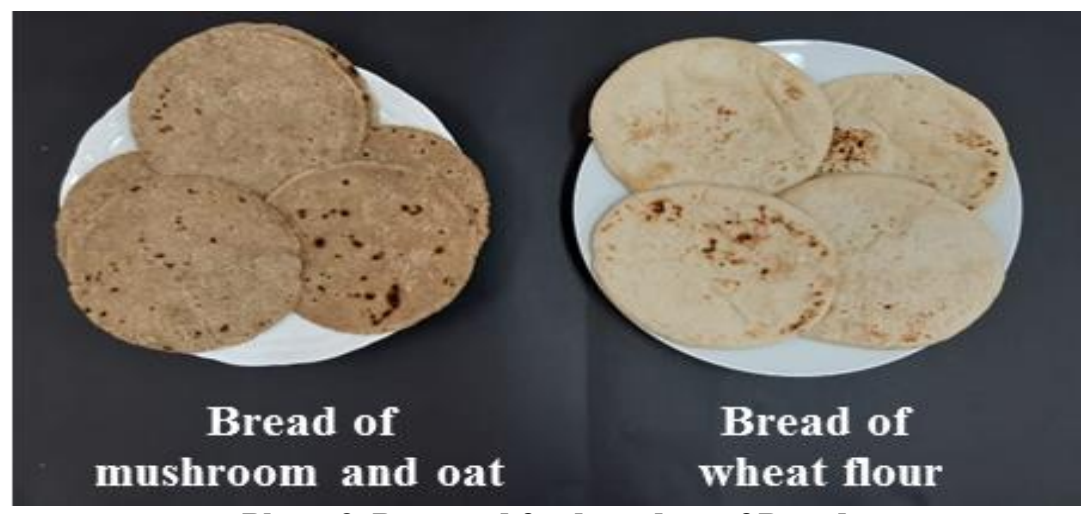

Photo 3. Prepared food product of Bread

Table 11. Sensory evaluation of Soup

$*$ : Statistically significant at $\mathrm{p} \leq 0.05$

\begin{tabular}{cccccc}
\hline Soup & Color & Taste & Odor & Texture & $\begin{array}{c}\text { Overall } \\
\text { acceptability }\end{array}$ \\
\hline Soup (meat) control & $8.35 \pm 0.07$ & $8.37 \pm 0.07$ & $8.41 \pm 0.08$ & $8.37 \pm 0.07$ & $8.32 \pm 0.06$ \\
Soup (Oat+ mushroom) & $6.55 \pm 0.07$ & $7.15 \pm 0.13$ & $6.61 \pm 0.08$ & $7.06 \pm 0.12$ & $6.52 \pm 0.07$ \\
\hline $\mathrm{T}$ & $19.779^{*}$ & $8.850^{*}$ & $18.516^{*}$ & $9.612^{*}$ & $20.396^{*}$ \\
$\mathrm{P}$ & $<0.001^{*}$ & $<0.001^{*}$ & $<0.001^{*}$ & $<0.001^{*}$ & $<0.001^{*}$ \\
\hline
\end{tabular}

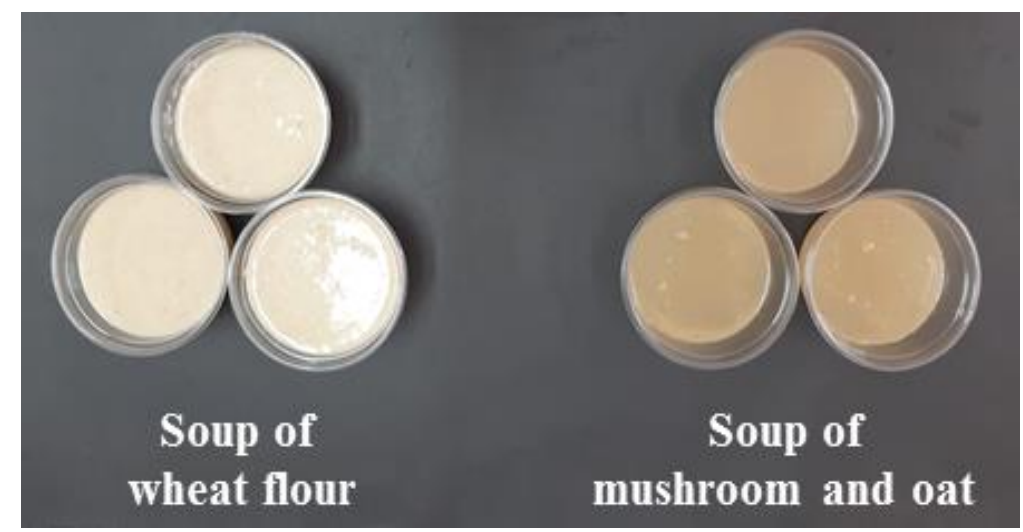

Photo 4. Prepared food product of Soup

Table 12. Sensory evaluation of mushroom plus oat mixture $(20+40 \%)$ food products

\begin{tabular}{cc}
\hline Food products & Overall acceptability \\
\hline Kofta & $8.62^{\mathrm{a}} \pm 0.09$ \\
Pizza & $8.10^{\mathrm{b}} \pm 0.14$ \\
Bread & $7.99^{\mathrm{b}} \pm 0.09$ \\
Soup & $6.52^{\mathrm{c}} \pm 0.07$ \\
\hline F & $104.619^{*}$ \\
$\mathrm{p}$ & $<0.001^{*}$ \\
LSD 5\% & 0.2749 \\
\hline
\end{tabular}

Data was expressed using Mean \pm SE.

Means in a column with same letters are not significant (and means with different letters are significant)

*: Statistically significant at $\mathrm{p} \leq 0.05$ 


\section{REFERENCE}

Amundsen, E. K., C. E. Henriksson, M. R. Holthe and P.Urdal. 2012. Is the blood basophil count sufficiently precise, accurate, and specific?: three automated hematology instruments and flow cytometry compared. American j. of clinical pathology, 137(1):86-92.

Baba, E., Ü.Acar, C.Öntaş, O. S.Kesbiç and S. Yilmaz. 2016. The use of Avena sativa extract against Aeromonas hydrophila and its effect on growth performance, hematological and immunological parameters in common carp (Cyprinus carpio). Italian j. of animal sci. 15(2), 325333.

Bigliardi, B. and F.Galati. 2013. Innovation trends in the food industry: the case of functional foods. Trends in Food Sci. \& Technology. 31(2), 118-129.

Bornare, D. and K. S. A.Khan. 2015. Physical and Sensory Evaluation of Cookies Incorporated with Oats and Honey. International $j$. of engineering research \& technology (IJERT). 4:407-411.

Boz, H. 2015. Phenolic amides (avenanthramides) in oats-a review. Czech j. of food sci. 33(5):399-404.

Budak, Y. U., M.Polat and K.Huysal. 2016. The use of platelet indices, plateletcrit, mean platelet volume and platelet distribution width in emergency non-traumatic abdominal surgery: a systematic review. Biochemia medica: Biochemia medica, 26(2):178-193.

Călinoiu, L. F. and D. C.Vodnar. 2018. Whole grains and phenolic acids: A review on bioactivity, functionality, health benefits and bioavailability. Nutrients. 10(11): 1615.

Cheung, P. C. 2010. The nutritional and health benefits of mushrooms. Nutrition Bulletin. 35(4):292-299.

Chi, Q., G.Wang, Y.Sheng, W.Xu, P.Shi, C.Zhao and K. Huang. 2017. Ethanolic extract of the Golden oyster mushroom, Pleurotus citrinopileatus (agaricomycetes), alleviates metabolic syndrome in diet-induced obese mice. International $j$. of medicinal mushrooms.19(11):10011008.

da Silva, C. K. F., Z. E.da Silva and V. C. Mariani. 2009. Determination of the diffusion coefficient of dry mushrooms using the inverse method. J.of food engineering. 95(1):1-10.

Davis, C. D. 2016. The gut microbiome and its role in obesity. Nutrition today. 51(4):167-174.

Deepalakshmi, K. and M.Sankaran. 2014. Pleurotus ostreatus: an oyster mushroom with nutritional and medicinal properties. J. of Biochemical Technology. 5(2):718-726.

Dong, J. L., Y. Y. Zhu, Y. L. Ma, Q. S.Xiang, R. L.Shen and Y. Q. Liu. 2016. Oat products modulate the gut microbiota and produce anti-obesity effects in obese rats. J. of functional foods. 25:408-420.

Farzana, T., T. N.Orchy, S.Mohajan, N.Sarkar and A.Kakon. 2019. Effect of incorporation of mushroom on the quality characteristics of blended wheat and oats flour. Archive of nutrition and public health. 1(1):1-10.
Friedman, M. 2016. Mushroom polysaccharides: chemistry and antiobesity, antidiabetes, anticancer, and antibiotic properties in cells, rodents, and humans. Foods. 5(4):80.

Galaly, S. R., W. G.Hozayen, K. A. Amin and S. M.Ramadan. 2014. Effects of Orlistat and herbal mixture extract on brain, testes functions and oxidative stress biomarkers in a rat model of high fat diet. Beni-suef university $j$. of basic and applied sci. 3(2):93-105.

Ganesan, K. and B. Xu. 2018. Anti-obesity effects of medicinal and edible mushrooms. Molecules. 23(11):2880.

Gani, A., S.Wani, F.Masoodi and G.Hameed. 2012. Wholegrain cereal bioactive compounds and their health benefits: a review. J. of food processing \& technology. 3(3):146-156.

Grundy, M. M. L., A. Fardet, S. M.Tosh, G. T.Rich and P. J.Wilde. 2018. Processing of oat: the impact on oat's cholesterol lowering effect. Food \& function. 9(3):13281343.

Hall, M. E., J. M.do Carmo, A. A.da Silva, J L. A.uncos, Z.Wang and J. E.Hall. 2014. Obesity, hypertension, and chronic kidney disease. International j. of nephrology and renovascular disease. 7-75.

Jin, X., L.Yi, M. 1.Chen, C. y.Chen, H.Chang, T.Zhang and M. t. Mi. 2013. Delphinidin-3-glucoside protects against oxidized low-density lipoprotein-induced mitochondrial dysfunction in vascular endothelial cells via the sodiumdependent glucose transporter SGLT1. PLoS One. 8(7):e68617.

Jopling, J., E.Henry, S. E.Wiedmeier and R. D. Christensen. 2009. Reference ranges for hematocrit and blood hemoglobin concentration during the neonatal period: data from a multihospital health care system. Pediatrics. 123(2):e333-e337.

Kirkpatrick, L. A. and B. C.Feeney. 2013. A simple guide to IBM SPSS statistics for version 20.0. Belmont, Calif: Wadsworth, Cengage Learning.

Kozarski, M., A.Klaus, D.Jakovljevic, N.Todorovic, J.Vunduk, P.Petrović and L.Van Griensven. 2015. Antioxidants of edible mushrooms. Molecules. 20(10):19489-19525.

Larmkie, H. L., J. P. N.Torgbor, B. A. M.Yaa, S.Christopher and D.Matilda. 2018. Sensory Attributes of Three Edible Tropical Mushrooms and Their Use in Formulating Food Products for Children 2-5 Years Old. International J. of Nutrition and Food Sci. 7(3):100-109.

Li, X., X.Cai, X.Ma, L. Jing, J.Gu, L.Bao and Y.Li. 2016. Short-and long-term effects of wholegrain oat intake on weight management and glucolipid metabolism in overweight type- 2 diabetics: a randomized control trial. Nutrients. 8(9):549.

Lin, J. P., C. J. O'Donnell, L. Jin, C. Fox, Q.Yang and L. A.Cupples. 2007. Evidence for linkage of red blood cell size and count: Genome-wide scans in the Framingham Heart Study. American j. of hematology. 82(7):605-610. 
Lopes-Virella, M., P.Stone and J. Colwell. 1977. Serum high density lipoprotein in diabetic patients. Diabetologia. 13(4):285-291.

Lugogo, N. L., D.Bappanad and M.Kraft. 2011. Obesity, metabolic dysregulation and oxidative stress in asthma. Biochimica et Biophysica Acta (BBA)-General Subjects. 1810(11):1120-1126.

Majtan, J. and M.Jesenak. 2018. $\beta$-Glucans: Multi-Functional Modulator of Wound Healing. Molecules. 23(4).

Martinez-Villaluenga, C. and E. Peñas. 2017. Health benefits of oat: current evidence and molecular mechanisms. Current Opinion in Food Sci. 14:26-31.

Mishra, R., Y.Mishra, P. Singh, B.Raghubanshi and R. Sharma. 2018. Nutritional and Sensory Evaluation of Oyster Mushroom Supplemented Daily Food Items. International J. of Current Microbiology and Applied Sci. 7(08):1465-1471.

Muszyńska, B., A. Grzywacz-Kisielewska, K.Kała and J. Gdula-Argasińska. 2018. Anti-inflammatory properties of edible mushrooms: A review. Food Chemistry. 243:373381.

Ndung'u, S., C.Otieno, C.Onyango and F.Musieba. 2015. Nutritional composition, physical qualities and sensory evaluation of wheat bread supplemented with oyster mushroom. American J. of Food Technology. 10(6):279288.

Paget, G. E. and G. M. Barnes. 1964. Toxicity tests. In D. R. Laurence \& A. L. Bacharach (Eds.), Evaluation of Drug Activities: Pharmacometrics (1:133-166). New York: Academic Press.

Peng, C. H., H. C. Chang, M. Y.Yang, C. N.Huang, S. J.Wang and C. J. Wang. 2013. Oat attenuate non-alcoholic fatty liver and obesity via inhibiting lipogenesis in high fat-fed rat. J. of Functional Foods. 5(1):53-61.

Rasane, P., A.Jha, L.Sabikhi, A.Kumar and V. Unnikrishnan. 2015. Nutritional advantages of oats and opportunities for its processing as value added foods-a review. J. of food sci. and technology. 52(2):662-675.

Rathore, H., S.Prasad and S.Sharma. 2017. Mushroom nutraceuticals for improved nutrition and better human health: A review. PharmaNutrition. 5(2):35-46.

Rebello, C. J., C. E.O’Neil and F. L.Greenway. 2016. Dietary fiber and satiety: the effects of oats on satiety. Nutrition Reviews. 74(2):131-147.

Rigo, A., P.Viglino and G. Rotilio.1975. Polarographic determination of superoxide dismutase. Analytical biochemistry.68(1):1-8.

Rop, O., J. Mlcek and T. Jurikova. 2009. Beta-glucans in higher fungi and their health effects. Nutrition reviews. 67(11):624-631.
Saba, N. H. 2012. Cooking is a sci. and an art. Cairo, Egypt: Dar El-Maaref.

Shawky, S. M. 2015. Effect of short-term high fat diet inducing obesity on hematological, some biochemical parameters and testicular oxidative stress in male rats. $J$. of Advanced Veterinary Research.5(4):151-156.

Sinha, A. K. 1972. Colorimetric assay of catalase. Analytical biochemistry. 47(2):389-394.

Sirag, H. 2009. Biochemical and hematological studies for the protective effect of oyster mushroom (Pleurotus ostreatus) against glycerol-induced Acute Renal Failure in rats. J. of Biological sci. 9(7):746-752.

Sirimanapong, W., A.Adams, E. L.Ooi, D. M.Green, D. K.Nguyen, C. L.Browdy and K. D.Thompson. 2015. The effects of feeding immunostimulant $\beta$-glucan on the immune response of Pangasianodon hypophthalmus. Fish \& shellfish immunology. 45(2):357-366.

Thiagarajan, P. and E.Besa. 2016. Platelet disorders overview of platelet disorders. Medscape.

Uluköy, G., E.Baba and C. Öntaş. 2016. Effect of oyster mushroom, Pleurotus ostreatus, extract on hemato-immunological parameters of Rainbow trout, Oncorhynchus mykiss. J. of the World Aquaculture Society. 47(5):676-684.

Valverde, M. E., T.Hernández-Pérez and O.Paredes-López. 2015. Edible mushrooms: improving human health and promoting quality life. International j. of microbiology. 376387.

Volman, J. J., J. D. Ramakers and J. Plat. 2008. Dietary modulation of immune function by beta-glucans. Physiol Behav.94(2):276-284.

Watts, B., G.Ylimaki, L.Jeffery and L.Elias. 1989. Sensory methods for food evaluation. The International Development Research Center, Ottawa. 160p.

Wendel, A. 1980. Glutathione peroxidase. Enzymatic basis of detoxication. 1:333-353.

Wood, P. J. 2010. Oat and rye $\beta$-glucan: properties and function. Cereal Chemistry. 87(4): 315-330.

Yeganeh, S., M. Teimouri and A. K.Amirkolaie. 2015. Dietary effects of Spirulina platensis on hematological and serum biochemical parameters of rainbow trout (Oncorhynchus mykiss). Research in Veterinary Sci. 101:84-88.

Zaki, H. and A.Hussien. 2018. Chemical, rheological and sensory properties of wheat-oat flour composite cakes and biscuits. J. of Productivity and Development. 23(2):287306.

Zhang, Y., T.Ni, D.Zhang, H.Liu, J.Wang and B. Sun. 2020. Consumption of avenanthramides extracted from oats reduces weight gain, oxidative stress, inflammation and regulates intestinal microflora in high fat diet-induced mice. J. of Functional Foods. 65:103774. 


\section{الملخص العربي}

تأثير المشروم والثوفان وخليطهما كأطعمة وظيفية على أنثطة مضادات الاكسدة، صور الام للفئران

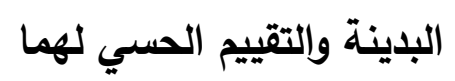

تسبي محمد شاد لطفي ، حسن الهندي و سمر محمد سالم شعوير

التجربة (^ أسابيح) أخذت عينات الدم لتقدير نشاط مضادات

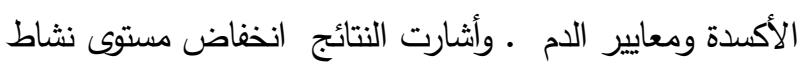

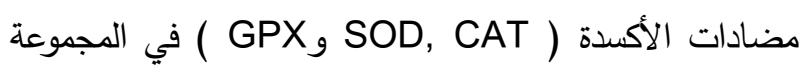
التي تغذت على وجبة عالية الدهون حيث كانت (r.r.

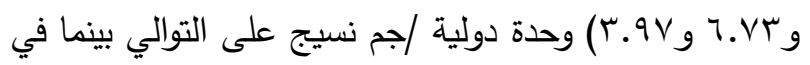

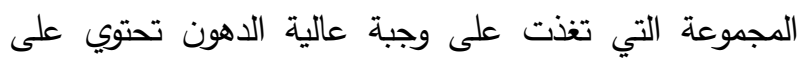

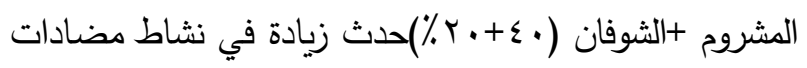

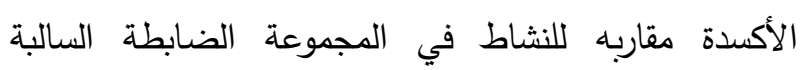

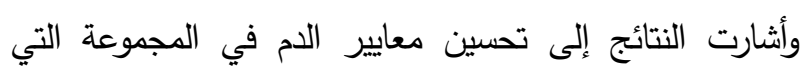

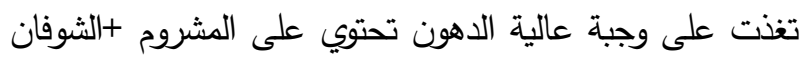

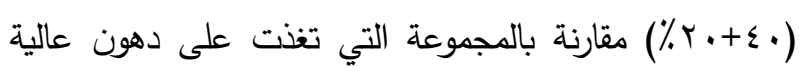

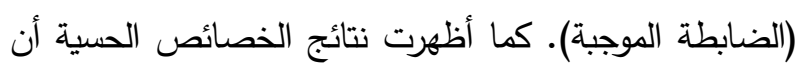

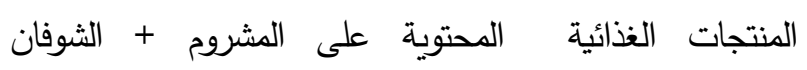

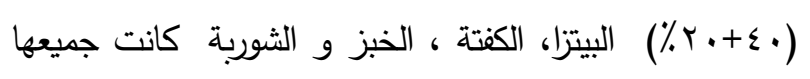
مقبول من قبل المحكمين. وتشير الدراسة إلى إمكانية استخدام

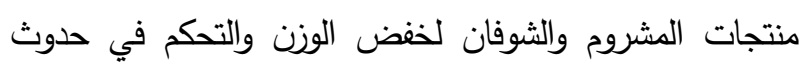
السمنة.

الكلمات الافتتاحية: الفئران البدينة - المشروم - الثوفان - مضادات الأكسدة - الخصائص الحسية.
تهدف الدراسة إلى تقييم تأثير فطر عيش الغراب (المشروم) والثوفان وخليطهما على نثاط مضادات الأكسدة

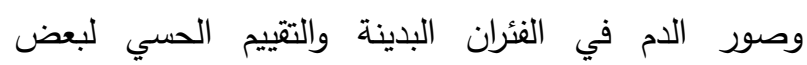

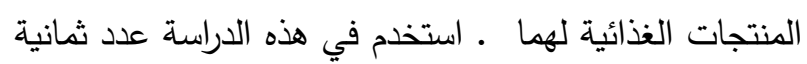

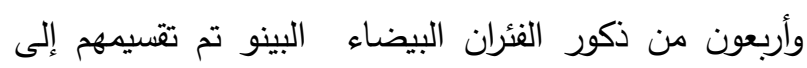
مجموعتين رئيسيتين. المجموعة الرئيسية الأولي تم تغذيتها تلفيأ علي الغذاء الأساسي واستخدمت كمجموعة ضابطة سالبة

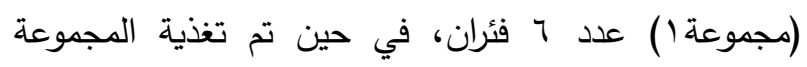

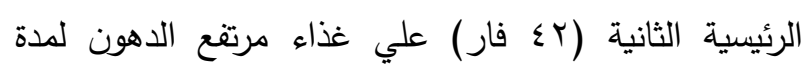

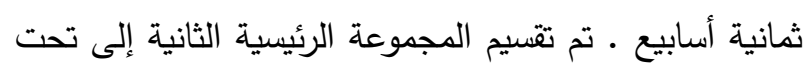

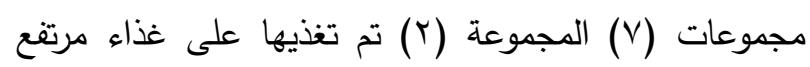

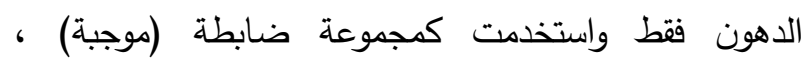
المجموعة (ץ) تم تغذيتها على غذاء مرتفع الدهون يحتوي

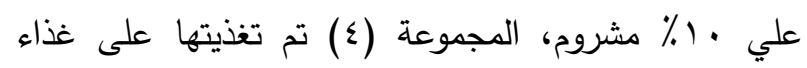

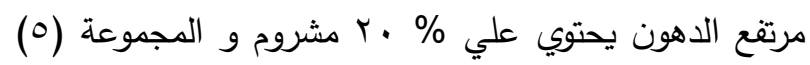

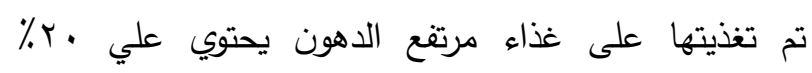
شوفان، المجموعة (؟) تم تغذيتها على غذاء مرتفع الدهون

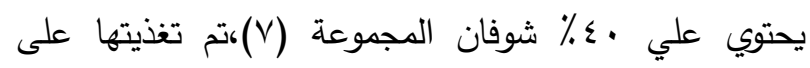

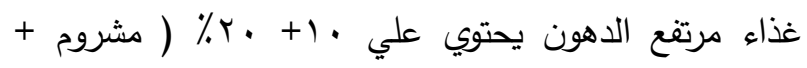

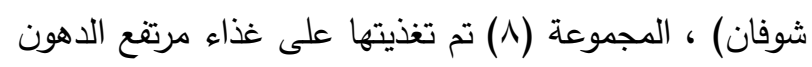
يحتوي علي •ץ+ • • ٪ ( مشروم + شوفان) .في نهاية فترة 